\title{
Batch-operation as a method to enhance oxygen supply in a constructed wetland
}

\author{
K. Karabelnik ${ }^{1,2}$, A. Noorvee ${ }^{1,2}$, E. Põldvere ${ }^{1,2}$ \& Ü. Mander ${ }^{1}$ \\ ${ }^{I}$ Department of Geography, Institute of Ecology and Earth Sciences, \\ University of Tartu, Estonia \\ ${ }^{2}$ Alkranel Ltd., 35 J. Hurda St., Tartu 51005, Estonia
}

\begin{abstract}
The removal of organic matter and nitrogen in constructed wetlands (CW) is highly dependent on the availability of dissolved oxygen in the treatment system. Therefore it is of great importance to develop innovative methods to enhance oxygen supply in the CW matrix. This paper focuses on and describes the methods used to enhance oxygen supply in CWs. Also, a pilot scale experimental batch-operated lightweight aggregate (LWA) filter system (FS) consisting of eight identical LWA filter cells (with a depth of $1.15 \mathrm{~m}$ and an area of $1 \mathrm{~m}^{2}$ each) was established during the summer of 2005 for the treatment of municipal wastewater. The main objective of this study was to evaluate the performance of the experimental batch-operated FS on the basis of performance indicators. During the experiments, the effect of different operational regimes on the purification efficiency of the filter system was also investigated. The highest purification efficiencies of $96 \%$ and $51 \%$ for $\mathrm{BOD}_{7}$ and $\mathrm{N}_{\text {tot }}$, respectively, were achieved when the recirculation rate of $200 \%$ was applied at the hydraulic retention time of $\sim 2$ days. The highest organic matter removal rate of the experimental $\mathrm{FS}$ as $\mathrm{K}_{\mathrm{BHT}}=0.19 \mathrm{~m} \mathrm{~d}^{-1}$ is approximately two times higher than the removal rate of typical horizontal-flow CWs. However, the highest aeration capacity of $21.1 \mathrm{gO}_{2} \mathrm{~m}^{-2} \mathrm{~d}^{-1}$ is somewhat lower than the average aeration capacity of vertical-flow CWs, and substantially lower than the aeration capacity of a VF filter with re-circulation or tidal-flow systems. As the aeration capacity of the system partly depends on the oxygen demand of inflow wastewater, it is necessary to carry out studies of shorter hydraulic loading rates in order to optimize the performance of experimental batch-operated FSs.
\end{abstract}

Keywords: aeration capacity; batch operation; constructed wetland; LWA filter system; oxygen supply; re-circulation. 


\section{Introduction}

In the past two decades, constructed wetland (CW) technology has been developed to a considerable extent, and the $\mathrm{CW}$ approach to wastewater treatment has become widespread throughout the world as an ecological alternative to conventional wastewater treatment systems.

Carbon compounds present in wastewater are degraded in CWs through both anaerobic and aerobic processes, but as the aerobic process is faster, most of the organic carbon is consumed by aerobic processes. As regards nitrogen removal, sequential nitrification/denitrification appears to be the major mechanism, with high respiratory oxygen demand and low oxygen availability in constructed wetlands making nitrification the rate-limiting step $[1,2]$.

There is substantial evidence that the removal of organic matter and nitrogen in CWs is, in addition to temperature, determined by the availability of dissolved oxygen in the treatment system [3-5]. Therefore it is of great importance to develop innovative methods to enhance oxygen supply in the $\mathrm{CW}$ matrix and thereby the purification efficiency of the treatment system in order to minimize the space needed for wastewater treatment.

This paper focuses on the methods used to enhance oxygen supply in CWs, such as vertical-flow systems, systems with effluent recirculation, systems with fluctuating water level, tidal-flow systems and batch-operated systems. The performance of a batch-operated $\mathrm{CW}$ compared to conventional $\mathrm{CWs}$ is also studied.

\subsection{Methods used to enhance oxygen supply in CWs}

The high oxygen demand of wastewater together with the limited oxygen supply of the $\mathrm{CW}$ filter often limits the amount of dissolved oxygen used for nitrification processes. Nitrification could also be limited by insufficient contact between wastewater and micro-organisms due to the lower oxygen consumption rate of autotrophic nitrifying bacteria compared to heterotrophic carbon consuming bacteria [6].

\subsubsection{Vertical-flow CWs}

In a vertical-flow (VF) filter, wastewater is pumped onto the filter body at alternating periods, water flows vertically through the filter media, is collected by the drainage system on the bottom of the filter and flows into the next stage. Effective aeration is achieved by generating a fast water flow through the filter media, the phenomenon called passive air-pump. Thus the filter consists of material with different hydraulic conductivity. Usually, the two VF filters are loaded intermittently, which allows the degradation of accumulated suspended organic material in order to prevent clogging of the filter [8] and also lets the surface dry out for certain periods of time [7].

VF ensures better oxygenation of filter media, which favours aerobic processes and therefore ensures better organic matter and ammonia nitrogen removal than horizontal-flow filter [5, 8-11]. It is shown [12, 5] that in a VF 
filter BOD and suspended solids (SS) can be removed successfully, and sufficient nitrification is achieved even at low temperatures.

A common problem regarding the VF filter is the uneven distribution of water onto the filter surface and the short contact time between wastewater and filter material. In addition, the VF filter does not assure sufficient total nitrogen (TN) removal if the anoxic conditions required for denitrification are not evolved.

\subsubsection{Re-circulation of treated water}

In order to improve the purification efficiency of $\mathrm{CW}$ systems, the re-circulation of treated water is often used [11-14]. Re-circulation is not used in horizontalflow (HF) filter systems, as the process considerably increases hydraulic loading. However, it proves to be appropriate in VF filters, as materials of much higher hydraulic conductivity are used in VF filters. Re-circulation assures better oxygenation of wastewater, as water is repeatedly pumped back onto the surface of the filter. Re-circulation also favours purification processes through longer contact time between wastewater and micro-organisms attached to the filter material [11].

The positive effect of re-circulation on purification efficiency, especially regarding $\mathrm{TN}$, have been described in several studies [12, 11, 14]. It has been shown that the re-circulation of treated water in a vegetated VF filter improves BOD and ammonia nitrogen removal [11]. Brix et al. [12] studied the effect of the re-circulation of treated water on denitrification processes occurring in the septic tank and found that the re-circulation rate of $100 \%(1: 1)$ resulted in $50 \%$ denitrification. This was concurrently more stable and effective when recirulation was applied. Noorvee [15] recommends that the re-circulation rate should be from 100 to 300 percent of the inflowing wastewater in order to achieve satisfactory results in terms of effective BOD and COD removal and nitrification/denitrification, as well as TSS removal.

\subsubsection{Batch-operated CW system}

In a batch operated $\mathrm{CW}$, the filter is rapidly filled to capacity, remains filled for a sufficient period of time and is repeatedly drained and refilled. The advantage of batch-operation over continuous-flow operation in wetland systems is supported by the fact that even at very low drain-fill frequencies, the batch operation of subsurface flow (SSF) CWs ensures that the microbial population at any given point will be exposed to decreasing organic carbon concentration, which allows the wetland environment to be subjected to temporal redox variation (between aerobic and anoxic conditions), therefore enhancing BOD and $\mathrm{N}$ removal [16].

\subsubsection{CW with fluctuating water level}

In CW systems with fluctuating water levels, the CW cells are filled and drained (water level fluctuation) with the same wastewater at a determined frequency over a certain period of time. When the filter is filled with wastewater, anoxic and anaerobic conditions are developed over a short period. During the draining process, additional flux of oxygen is sucked into the filter, which favours aerobic treatment processes. Thus it is necessary to perform several short fill-drain cycles in order to enhance nitrification processes [1]. 
Tanner et al. [1] studied the effect of water level fluctuation on COD, ammonia nitrogen and TN removal in CW mesocosms and found that the increase in frequency of short fill-drain cycles (0-6 cycles per day over 7 days) remarkably improved the purification efficiency of organic matter and reduced forms of nitrogen, and that COD and TN removal can be enhanced by optimizing the frequency of fill-drain cycles.

\subsubsection{Tidal-flow CW}

Several recent studies have shown that the purification efficiency of CWs can be enhanced by applying an innovative operation method called "tidal-flow". [13, $17,18]$. During the tidal-flow operation, the wetland matrix is alternately filled with wastewater and drained. When the wetland is filled, air is repelled from the matrix. When the wetland is drained, air is drawn from the atmosphere into the matrix [17]. Tidal-flow operation has the potential to enhance the removal of BOD through aerobic processes and the removal of ammonia nitrogen through nitrification, as the maximum pollutant-biofilm contact is established and the rate of oxygen transfer is increased during the operation [13].

Nitrogen removal through sequential nitrification and denitrification in tidalflow systems is mainly based on adsorption processes [19, 18]. During the process ammonium ions $\left(\mathrm{NH}_{4}^{+}\right)$present in wastewater adsorb onto a negatively charged biofilm. During the draining process, atmospheric oxygen is drawn down into the filter body, resulting in rapid aeration of the biofilm and nitrification of $\mathrm{NH}_{4}^{+}$. Nitrate ions rapidly desorb from the biofilm into the wastewater during the subsequent filling of the filter and are used as an electron acceptor during denitrification [18]. Thus the essential factor for nitrogen removal in tidal-flow systems is absorption of $\mathrm{NH}_{4}^{+}$ions for the nitrification process $[19,1]$, which depends on the characteristics, especially on the cation exchange capacity of the filter material used in treatment system [20].

Austin et al. [18] conducted experiments with a vegetated tidal-flow CW system with re-circulation using artificial wastewater $\left(\mathrm{BOD}_{5}=402 \mathrm{mgl}^{-1}\right.$; $\mathrm{N}_{\text {tot }}=38 \mathrm{mgl}^{-1} ; \mathrm{Q}=1.7 \mathrm{~m}^{3} \mathrm{~d}^{-1}$ ), and achieved $\mathrm{BOD}_{5}$ and $\mathrm{N}_{\text {tot }}$ concentrations below $10 \mathrm{mg}^{-1}$, showing that tidal VF CW systems ensure sufficient TN removal through a simultaneous nitrification/denitrification process. Studies $[18,17]$ have shown that tidal-flow CW systems require substantially less space than conventional CW systems to obtain the same purification efficiency. In addition, nitrogen removal through the nitrification/denitrification process in the tidal-flow system is energetically more effective, as atmospheric oxygen is used for the nitrification. The major disadvantage of tidal-flow CW systems is that there is no good technical solution to use them in cold climate conditions if a hard freeze is possible [21].

It appears that each of the method described above has its advantages and disadvantages. Prior experiments have yielded promising results in the testing of methods that use water level fluctuation and concurrent variable redox conditions such as batch-operation, water level fluctuation and tidal-flow operation. The aim of developing new operating methods is to enhance purification efficiency and reduce the space requirements of $\mathrm{CW}$ systems. There is, however, still little information available on the performance of batch- 
operated and tidal-flow CWs, as most of the studies that have been carried out so far have been conducted in lab conditions using artificial wastewater [16-18, 22].

The main objective of this study was to investigate the anticipated advantages of a batch-operated CW system on conventional CW systems (HF and VF filters) on the basis of a batch-operated CW pilot. During the test period, the purification and aeration capacity of the batch-operated pilot was studied, and the effect of different operational regimes on the purification efficiency of the filter system was also investigated.

\section{Materials and methods}

During summer 2005, a pilot-scale batch-operated filter was established near the existing activated sludge treatment plant (ASTP) in Ilmatsalu for the treatment of municipal wastewater from Ilmatsalu settlement.

\subsection{Experimental design}

\subsubsection{Construction}

The system consists of a septic tank $\left(2 \mathrm{~m}^{3}\right)$, distribution well, eight identical lightweight aggregate (LWA) filter cells operated in a batch mode (with a depth of $1.15 \mathrm{~m}$ and an area of $1 \mathrm{~m}^{2}$ each) and an outflow/ recirculation well (Fig. 1). As the experimental period of the pilot $\mathrm{CW}$ is expected to be only one year, the cells were not planted. Therefore FS do not meet the strict definition of a wetland, and we used the term "LWA filter system". During the winter, when the ambient temperatures were below zero, the filter and the covers of wells were

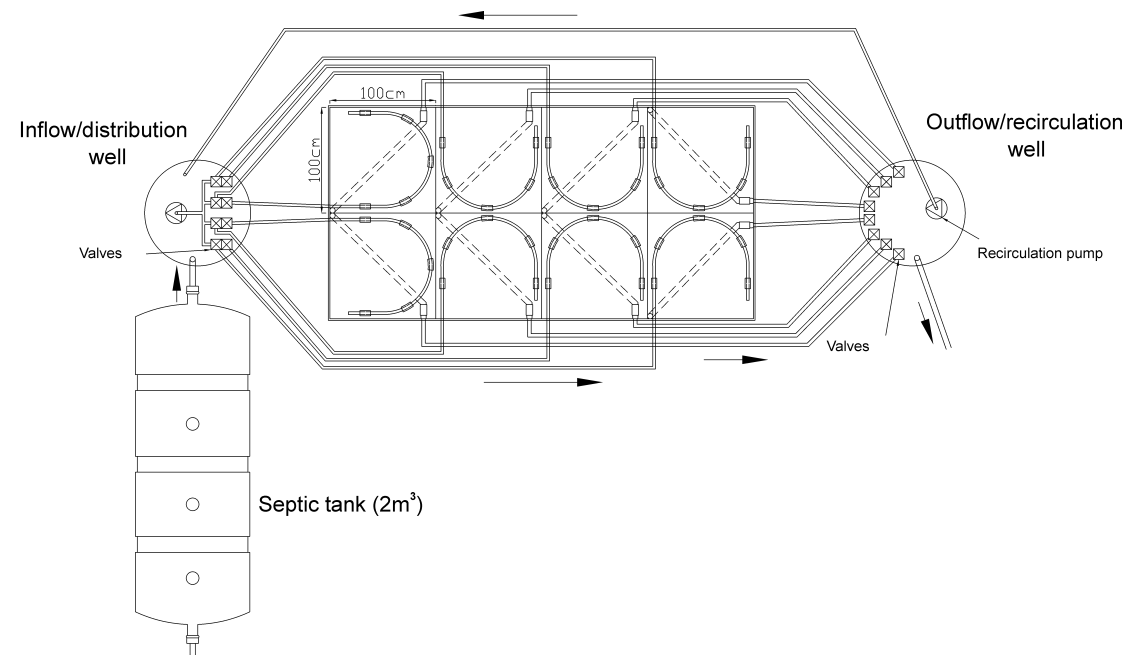

Figure 1: $\quad$ Plan view of Ilmatsalu batch-operated SF with associated septic tank, inflow and outflow well. 
isolated with $50 \mathrm{~mm}$ foamed plastic to keep the system from freezing due to its small dimensions.

\subsubsection{Filter material}

The cells are filled with a 1.15 m deep LWA. The LWA used in the Ilmatsalu pilot filter system is produced from local clay mineral in Estonia (trademark name Filtralite S) and does not have characteristics of Filtralite-P, for instance high phosphorus sorption capacity as reported by Jenssen and Krogstad (2003). It is, however, suitable for use in CWs due to its high hydraulic conductivity, porosity and good insulation properties [23]. The fraction of 2-4mm was used in all of the cells. The porosity of the humid LWA measured at site was $0.43 \mathrm{~m}^{3} \mathrm{~m}^{-3}$.

\subsection{Operation}

The hydraulic and pollution load of the Ilmatsalu LWA filter is determined by the test regime, the pore volume of the filter material and the water level in the wetland cells. While operating in batch mode, it is possible to re-circulate the treated water. The batch cycle consists of filling time, incubation time (variable), draining time ( $\sim 0.5-1$ hour) and recuperation time (up to $\sim 24 \mathrm{~h}$ ). The inflow and outflow fluxes of the cells are controlled by $25 \mathrm{~mm}$ solenoid valves installed in the inflow and outflow wells. As the hydraulic load of the Ilmatsalu LWA filter system was $\sim 0.5 \mathrm{~m}^{3}$ during the six test periods, the hydraulic retention time (HRT) of the septic tank was 4 days.

Wastewater from the grit channel of the ASTP is first pumped into the septic tank and further flows to the inflow well, from which it is pumped to the cells through solenoid valves. The cells are filled and drained in rotary mode: when the first cell is filled, the next is drained, etc. Pumps and valves are operated by a controller installed in the service building of the ASTP. The time between the fill and drain operation of the same cell is the incubation time, and the time between drain and fill operation of the same cell is the recuperation (rest) time. The recuperation (rest) period allows for the degradation of accumulated suspended organic material in order to prevent clogging of the filter [8]. In addition, intermittent flushing lets the surface dry out for certain periods of time [7]. Recirculation of the treated water is achieved by pumping the water from the outflow well back to the inflow well at the same time as filling takes place.

\subsubsection{Operational regimes}

Different operational regimes were tested during the experiments. The variations in loading rates are mainly dictated by varying incubation and recuperation time, loading rate and re-circulation rate. The FS has been in operation from the beginning of November 2005, and this paper covers the experimental data about 6 different operational regimes with hydraulic load, incubation and recuperation times, re-circulation rates and water quality parameters in the inflow reported in Table 1 .

\subsection{Sampling and comparison parameters}

Water grab samples from the inflow of the cells (outflow of the septic tank) and the outflow of the cells were taken randomly once a week. Water samples were 
Table 1: $\quad$ Parameters of different operational regimes (recirculation rate is given as a percent of daily inflow flow rate) and average values of water quality parameters in the inflow of the studied FS.

\begin{tabular}{|c|c|c|c|c|c|c|}
\hline \multirow[t]{2}{*}{ Parameter } & \multicolumn{6}{|c|}{ Operational regime } \\
\hline & 1 & 2 & 3 & 4 & 5 & 6 \\
\hline Duration & $\begin{array}{l}\text { Nov- } \\
\text { Dec }\end{array}$ & $\begin{array}{l}\text { Jan- } \\
\text { Mar }\end{array}$ & $\begin{array}{l}\text { Mar- } \\
\text { May }\end{array}$ & $\begin{array}{c}\text { May- } \\
\text { Jul }\end{array}$ & Aug-Oct & Oct-Dec \\
\hline Water level in SF cell (m) & 1.1 & 0.8 & 1.1 & 1.1 & 1.1 & 1.1 \\
\hline Incubation time $(\mathrm{d})$ & 7 & $\sim 5.3$ & $\sim 5.3$ & 3.5 & 2.3 & 1.8 \\
\hline Recuperation time (h) & $\sim 23$ & $\sim 17$ & $\sim 17$ & $\sim 11$ & $\sim 7$ & $\sim 5$ \\
\hline Re-circulation rate $(\%)$ & 0 & 0 & 20 & 100 & 200 & 300 \\
\hline $\mathrm{Q}\left(\mathrm{m}^{3} \mathrm{~d}^{-1}\right)$ & 0.47 & 0.46 & 0.53 & 0.47 & 0.47 & 0.47 \\
\hline $\mathrm{pH}$ & 7.5 & 7.3 & 7.3 & 7.2 & 7.2 & 7.3 \\
\hline Temp $\left({ }^{\circ} \mathrm{C}\right)$ & 5.4 & 3.1 & 7.3 & 13.4 & 14.6 & 8.4 \\
\hline $\mathrm{BOD}_{7}\left(\mathrm{mg} \mathrm{l}^{-1}\right)$ & 135 & 191 & 168 & 237 & 206 & 100 \\
\hline $\operatorname{TSS}\left(\mathrm{mg} \mathrm{l}^{-1}\right)$ & 33 & 48 & 37 & 66 & 97 & 55 \\
\hline $\mathrm{COD}_{\mathrm{Cr}}\left(\mathrm{mg} \mathrm{l}^{-1}\right)$ & 224 & 311 & 248 & 385 & 383 & 163 \\
\hline $\mathrm{N}_{\text {tot }}\left(\mathrm{mg} \mathrm{l}^{-1}\right)$ & 54 & 44 & 33 & 68 & 82 & 40 \\
\hline$P_{\text {tot }}\left(\mathrm{mg} \mathrm{l}^{-1}\right)$ & 6.6 & 6.6 & 5.8 & 8.1 & 10.3 & 6.6 \\
\hline
\end{tabular}

analyzed by an accredited laboratory according to Estonian standards for $\mathrm{pH}$, $\mathrm{BOD}_{7}, \mathrm{SS}, \mathrm{COD}_{\mathrm{Cr}}, \mathrm{N}_{\text {tot }}, \mathrm{NH}_{4}-\mathrm{N}, \mathrm{NO}_{2}-\mathrm{N}, \mathrm{NO}_{3}-\mathrm{N}, \mathrm{P}_{\text {tot }}$. Portative measures of temperature and dissolved $\mathrm{O}_{2}$ were measured on site. A total of 8,9 and 7 samples were taken during the first, second and third operational regime respectively.

This paper presents the data and the purification efficiencies of 6 different operational regimes in the pilot FS. For comparison of purification efficiencies, $\mathrm{BOD}_{7}, \mathrm{COD}_{\mathrm{Cr}}, \mathrm{SS}, \mathrm{N}_{\text {tot }}$, and $\mathrm{P}_{\text {tot }}$ are used as performance indicators. In addition, the oxygen demand (OD) of the wastewater was calculated on the basis of the following equation:

$$
\mathrm{OD}=\left[\left(\mathrm{BOD}_{\text {in }}-\mathrm{BOD}_{\text {out }}\right)+\left(\mathrm{NH}_{4}-\mathrm{N}_{\text {in }}-\mathrm{NH}_{4}-\mathrm{N}_{\text {out }}\right) * 4.3\right]^{*} \mathrm{Q},
$$

where $\mathrm{OD}$ is oxygen demand $\left(\mathrm{gO}_{2} / \mathrm{d}\right) ; \mathrm{BOD}_{\text {in }}$ is $\mathrm{BOD}_{7}$ concentration in the inflow of $\mathrm{FS}\left(\mathrm{gO}_{2} \mathrm{~m}^{-3}\right)$; $\mathrm{BOD}_{\text {out }}$ is the Estonian effluent standard for $\mathrm{BOD}_{7}$ in treatment plants $<2000$ pe $\left(15 \mathrm{~g} \mathrm{O}_{2} \mathrm{~m}^{-3}\right) ; \mathrm{NH}_{4}-\mathrm{N}_{\text {in }}$ is $\mathrm{NH}_{4}-\mathrm{N}$ concentration in the inflow of FS $\left(\mathrm{g} \mathrm{m}^{-3}\right)$; $\mathrm{NH}_{4}-\mathrm{N}_{\text {out }}$ - since there is no exact effluent standard for treatment plants smaller than 2000 pe in Estonia, the set target is that all the $\mathrm{NH}_{4}-\mathrm{N}$ should be removed $\left(0 \mathrm{~g} \mathrm{~m}^{-3}\right) ; \mathrm{Q}$ - flow rate $\left(\mathrm{m}^{-3} \mathrm{~d}^{-1}\right)$.

When we replace the standard values $\left(\mathrm{BOD}_{\text {out }}\right.$ and $\left.\mathrm{NH}_{4}-\mathrm{N}_{\text {out }}\right)$ in Eqn. 1 with the real values of effluent concentrations during the experiments, we obtain the total aeration capacity $\left(\mathrm{gO}_{2} \mathrm{~d}^{-1}\right)$ of the $\mathrm{FS}$, and when we divide it with the area of the FS, we obtain the specific aeration capacity of the FS $\left(\mathrm{gO}_{2} \mathrm{~m}^{-2} \mathrm{~d}^{-1}\right)$.

\section{Results and discussion}

\subsection{Purification efficiencies}

The purification efficiencies of $\mathrm{BOD}_{7}, \mathrm{~N}_{\text {tot }}$ and $\mathrm{P}_{\text {tot }}$ of $88 \%, 28 \%$ and $48 \%$, respectively, were achieved as an average of six test periods (Table 2). The 
highest purification efficiencies of $96 \%$ and $51 \%$ for $\mathrm{BOD}_{7}$ and $\mathrm{N}_{\text {tot }}$ respectively, were achieved when the recirculation rate of $200 \%$ was applied at the same hydraulic loading rate. The main factors affecting the performance of the batchoperated $\mathrm{FS}$ as concerns $\mathrm{BOD}_{7}$ and $\mathrm{N}_{\text {tot }}$ removal are water temperature and recirculation rate, in which the effect of recirculation and thus retention time was more protruding [24].

Table 2: $\quad$ Average purification efficiencies (PE, \%) of organic matter (by $\mathrm{BOD}_{7}$ ), total suspended solids, $\mathrm{COD}_{\mathrm{cr}}, \mathrm{N}_{\text {tot }}$ and $\mathrm{P}_{\text {tot }}$ at the outflow of the filter system (FS).

\begin{tabular}{|l|r|r|r|r|r|r|}
\hline \multirow{2}{*}{ PE at outflow (\%) } & \multicolumn{7}{|c|}{ Operational regime } \\
\cline { 2 - 8 } & 1 & 2 & 3 & 4 & \multicolumn{1}{c|}{5} & \multicolumn{1}{c|}{6} \\
\hline $\mathrm{BOD}_{7}$ & 88 & 74 & 83 & 91 & 96 & 95 \\
\hline $\mathrm{TSS}$ & 82 & 91 & 81 & 83 & 84 & 89 \\
\hline $\mathrm{COD}_{\mathrm{Cr}}$ & 70 & 61 & 69 & 83 & 90 & 85 \\
\hline $\mathrm{N}_{\text {tot }}$ & 16 & 0 & 8 & 43 & 51 & 48 \\
\hline $\mathrm{P}_{\text {tot }}$ & 62 & 36 & 41 & 53 & 53 & 44 \\
\hline
\end{tabular}

\subsection{Rate of organic matter removal}

In order to compare the performance of batch-operated FS with other systems, the rate of organic matter removal is calculated by using the following "Kickuth" equation, which is widely used for constructed wetlands in the secondary and tertiary treatment of municipal sewage [17]:

$$
A_{h}=\frac{\left(\ln C_{0}-\ln C_{e}\right) \times Q}{K_{B O D}},
$$

where $Q_{\mathrm{d}}$ is the average daily flow rate of the sewage $\left(\mathrm{m}^{3} / \mathrm{d}\right) ; C_{0}$ and $C_{\mathrm{e}}$ are values of $\mathrm{BOD}_{7}\left(\mathrm{mgO}_{2} / \mathrm{l}\right)$ at the inlet and outlet of the FS respectively; $A \mathrm{~h}$ is surface area $\left(\mathrm{m}^{2}\right)$ and $K_{\mathrm{BOD}}$ is the rate constant $(\mathrm{m} / \mathrm{d})$, when the removal of organic matter is described using first-order kinetics. Although there is no clear evidence that the rate of organic matter removal in constructed wetlands is indeed first-order, especially as concerns the treatment of strong sewage, and many studies have argued that position [26], it may still be used as a comparison method for different FS [17]. Table 3 presents the $K_{\mathrm{BOD}}$ values for different operational regimes using average data about $\mathrm{BOD}_{7}$ concentrations.

Table 3: $\quad$ Values of $K_{\mathrm{BOD}}$ for different operational regimes.

\begin{tabular}{|l|c|c|c|c|c|c|}
\hline Operational regime & 1 & 2 & 3 & 4 & 5 & 6 \\
\hline $\mathrm{K}_{\mathrm{BOD}}$ value & 0.13 & 0.08 & 0.12 & 0.14 & 0.19 & 0.18 \\
\hline
\end{tabular}

As shown in Table 3, the $\mathrm{K}_{\mathrm{BOD}}$ values range between $0.08-0.19 \mathrm{~m} \mathrm{~d}^{-1}$, which are higher than reported for typical values of $0.07-0.1 \mathrm{~m} \mathrm{~d}^{-1}$ for HF filters in the UK [25]. The average value of $\mathrm{K}_{\mathrm{BOD}}$ during the first three operational regimes was $0.11 \mathrm{~m} \mathrm{~d}^{-1}$, but the average value of $\mathrm{K}_{\mathrm{BOD}}$ during the next three operational regimes was $0.17 \mathrm{~m} \mathrm{~d}^{-1}$, indicating the positive effect of re-circulation on the rate 
of organic matter removal. Nevertheless, $\mathrm{K}_{\mathrm{BOD}}$ values reported in Table 3 are lower than reported by Sun et al. [17] for four-stage tidal-flow FSs without recirculation $\left(0.28-0.40 \mathrm{~m} \mathrm{~d}^{-1}\right)$ and with $100 \%$ re-circulation $\left(0.38-0.93 \mathrm{~m} \mathrm{~d}^{-1}\right)$.

\subsection{Aeration capacity}

In addition to the rate of organic matter removal, another typical parameter used to estimate the performance of an FS is aeration capacity $\left(\mathrm{gO}_{2} \mathrm{~m}^{-2} \mathrm{~d}^{-1}\right)$, which shows the amount of oxygen that is introduced into wastewater per unit of area per day. In order to estimate the performance of an FS, it is necessary to compare he aeration capacity with the oxygen demand of the inflow wastewater to the FS $\left(\mathrm{gO}_{2} \mathrm{~m}^{-2} \mathrm{~d}^{-1}\right)$. Table 4 reports the average values of the oxygen demand of wastewater in the inflow of the FS and aeration capacity during the six operational periods calculated using the equations presented in chapter 2.3.

Table 4: Average values of the oxygen demand of wastewater and aeration capacity of FS during the six operational periods.

\begin{tabular}{|l|r|r|r|r|c|c|}
\hline Operational regime & \multicolumn{1}{|c|}{1} & \multicolumn{1}{c|}{2} & \multicolumn{1}{c|}{3} & \multicolumn{1}{c|}{5} & \multicolumn{1}{c|}{5} & \multicolumn{1}{c|}{6} \\
\hline Oxygen demand $\left(\mathrm{gO}_{2} \mathrm{~m}^{-2} \mathrm{~d}^{-1}\right)$ & 19.1 & 19.4 & 19 & 28.2 & 29.2 & 13.1 \\
\hline Aeration capacity $\left(\mathrm{gO}_{2} \mathrm{~m}^{-2} \mathrm{~d}^{-1}\right)$ & 8.5 & 8 & 10.7 & 20.1 & 21.1 & 10.3 \\
\hline
\end{tabular}

According to the results reported in Table 4, the highest aeration capacity of $21.1 \mathrm{gO}_{2} \mathrm{~m}^{-2} \mathrm{~d}^{-1}$ was achieved during the $5^{\text {th }}$ operational period, when the recirculation rate of $200 \%$ was applied. Also, the increase in re-circulation rates during the last three operational periods improved the average aeration capacity of the FS about twofold compared to the average aeration capacity during the first three operational periods. In the case of VF filters, the average aeration capacity is considered to be $30 \mathrm{gO}_{2} \mathrm{~m}^{-2} \mathrm{~d}^{-1}[27,25]$, and could reach up to 50-90 $\mathrm{gO}_{2} \mathrm{~m}^{-2} \mathrm{~d}^{-1}$ without re-circulation [9]. Sun et al. [11] found that the aeration capacity of the VF filter increased from $29.7 \mathrm{gO}_{2} \mathrm{~m}^{-2} \mathrm{~d}^{-1}$ to $57.1 \mathrm{gO}_{2} \mathrm{~m}^{-2} \mathrm{~d}^{-1}$ when re-circulation was applied. Furthermore, Sun et al. [17] reports an aeration capacity of up to $473 \mathrm{gO}_{2} \mathrm{~m}^{-2} \mathrm{~d}^{-1}$ in the tidal-flow system. Therefore the aeration capacity of the Ilmatsalu batch-operated FS is comparable to a VF filter when recirculation of effluent is applied, but is substantially lower than the aeration capacity of a VF filter with re-circulation or tidal-flow systems. However, when comparing the aeration capacities of different systems, the oxygen demand of inflow wastewater has also been taken into consideration, as the aeration capacity of the systems depends on the oxygen demand of wastewater. The latter also explains the slightly lower aeration capacity during the $6^{\text {th }}$ operational period compared to the $5^{\text {th }}$ period, regardless of the application of the higher recirculation rate.

\section{Conclusions}

There are several operational methods used to enhance oxygen supply in CWs, such as vertical-flow systems, systems with effluent recirculation, systems with fluctuating water level, tidal-flow systems and batch-operated systems. 
The pilot scale batch-operated FS has shown $\mathrm{BOD}_{7}, \mathrm{~N}_{\text {tot }}$ and $\mathrm{P}_{\text {tot }}$ purification efficiencies of $88 \%, 28 \%$ and $48 \%$ respectively, as an average of six test periods. However, the highest purification efficiencies of $96 \%$ and $51 \%$ for $\mathrm{BOD}_{7}$ and $\mathrm{N}_{\text {tot }}$ respectively, were achieved when the recirculation rate (given as percent of the daily inflow flow rate) of $200 \%$ was applied at the hydraulic retention time of $\sim 2$ days.

During the study, the comparison between batch-operated and conventional CWs were made, and the possible advantages of batch-operated CWs were analyzed on the basis of the organic matter removal rate calculated by the "Kickuth" equation and the aeration capacity of the FS. The highest organic matter removal rate of $K_{\mathrm{BHT}}=0.19 \mathrm{~m} \mathrm{~d}^{-1}$ is approximately two times higher than the removal rate of typical horizontal-flow $\mathrm{CW}$ (that our experimental system most closely matched in terms of flow path) reported in the literature. However, the highest aeration capacity of $21.1 \mathrm{gO}_{2} \mathrm{~m}^{-2} \mathrm{~d}^{-1}$ is somewhat lower than the average aeration capacity of vertical-flow CWs, and substantially lower than the aeration capacity of a VF filter with re-circulation or tidal-flow systems. We believe that the performance indicators should be interpreted regarding the low inflow concentrations of wastewater, and as the shorter hydraulic retention times could be applied during the future studies, the performance indicators of batchoperated FS are expected to improve substantially.

\section{Acknowledgements}

This study was supported by Enterprise Estonia project No. EU19215, "Hybrid constructed wetlands for wastewater treatment", Estonian Science Foundation Grant No. 6083 and Target Funding Project No. 0182534s03 of the Ministry of Education and Science of Estonia. We acknowledge Dr. Krista Lõhmus of the Department of Geography of the Institute of Ecology and Earth Sciences of the University of Tartu for her help with the statistical analysis of the data.

\section{References}

[1] Tanner, C. C., D'Eugenio, J., McBride, G. B., Sukias, J. P. S. and Thompson, K. Effect of water level fluctuation on nitrogen removal from constructed wetland mesocosms. Ecol. Eng., 12(1), pp. 67-92, 1999.

[2] Harris, T. Z. and Mæhlum, T. Nitrogen removal in light-weight aggregate pre-treatment filter columns and mesocosm wetlands. In: Constructed Wetlands for Wastewater Treatment in Cold Climates. Advances in Ecological Sciences 11, Ü. Mander and P. D. Jenssen (eds.), WIT Press, Southampton, Boston, pp. 273-297, 2003.

[3] Kadlec, R. H. and Knight, R. L. Treatment Wetlands. Lewis Publishers: Boca Raton, New York, London, Tokyo, 893 p, 1996.

[4] Allen, W. C., Hook, P. B., Biederman, J. A., Stein, O. R. Temperature and wetland plant species effects on wastewater treatment and root zone oxidation. J. Environ. Qual., 31 (3), pp. 1010-1016, 2002. 
[5] Noorvee, A., Põldvere, E. and Mander, Ü. The effect of a vertical flow filter bed on a hybrid constructed wetland system. Wat. Sci. Tech., 51(9), pp. 137-144, 2005.

[6] Sikora, F. J., Zhu, T, Behrends, L. L., Steinberg, S. L., Coornod, H. S. Ammonium removal in constructed wetlands recirculating subsurface flow: removal rates and mechanisms. Wat. Sci. Tech., 48(5), pp. 193-202, 1995.

[7] von Felde, K. and Kunst, S. N- and COD-removal in vertical-flow systems. Wat. Sci. Tech., 35(5), pp. 79-85, 1997.

[8] Green, M., Friedler, E., Ruskol, Y. and Safrai, I. Investigation of alternative method for nitrification in constructed wetlands. Wat. Sci. Tech., 35(5), pp. 63-70, 1997.

[9] Cooper, P., Griffin, P., Humphries, S. and Pound, A. Design of a hybrid reed bed system to achieve complete nitrification and denitrification of domestic sewage. Wat. Sci. Tech., 40(3), pp. 283-289, 1999.

[10] Mæhlum, T. and Stålnacke, P. Removal efficiency of three cold-climate constructed wetlands treating domestic wastewater: effects of temperature, seasons, loading rates and input concentrations. Wat. Sci. Tech., 40(3), pp. 273-281, 1999.

[11] Sun G., Gray K. R., Biddlestone A. J., Allen S., Cooper D. J. Effect of effluent recirculation on the performance of a reed bed system treating agricultural wastewater. Process Biochem., 39 (3), pp. 351-357, 2003.

[12] Brix, H., Arias, C. A., Johansen, N. H. BOD and nitrogen removal from municipal wastewater in an experimental two-stage vertical flow constructed wetland system with recycling. In: Proceedings of the $8^{\text {th }}$ International Conference on Wetland Systems for Water Pollution Control, vol. 1, Arusha, Tanzania, 16-19 September, pp. 400-410, 2002.

[13] Sun, G., Gray, K. R, Biddlestone, A. J. Treatment of agricultural wastewater in a pilot-scale tidal flow reed bed system. Environ. Technol. 20(2), pp. 233-237, 1999.

[14] Green, M., Gidron, E., Lahav, O., Tarre, S. Treatment of dairy wastewater using a vertical bed with passive aeration. In: Proceedings of the 8th International Conference on Wetland Systems for Water Pollution Control, vol. 1, Arusha, Tanzania, 16-19 September, pp. 324-332, 2002.

[15] Noorvee, A. The applicability of hybrid subsurface flow constructed wetland systems with re-circulation for wastewater treatment in cold climates. Doctoral theses. Department of Geography, Institute of Ecology and Earth Sciences, University of Tartu, Tartu University Press, Tartu, Estonia. 2007, pp. 44, 2007.

[16] Stein, O. R., Hook, P. B., Biederman, J. A., Allen W. C. and Borden, D. J. Does batch operation enhance oxidation in subsurface constructed wetlands? Wat. Sci. Tech., 48(5), pp. 149-156, 2003.

[17] Sun, G., Zhao, Y. and Allen, S. Enhanced removal of organic matter and ammoniacal-nitrogen in a column experiment of tidal flow constructed wetland system. Journal of Biotechnology, 115(2), pp. 189-197, 2005. 
[18] Austin, D., Lohan, E., Verson, E. Nitrification and denitrification in a tidal vertical flow wetland pilot. Proceedings of the Water Environment Technical Conference (Los Angeles, California), 2003.

[19] McBride, G. B. and Tanner C. C. Modelling biofilm nitrogen transformations in constructed wetland mesocosms with fluctuating water levels. Ecol. Eng. 14 (2000), pp. 93-106, 2000.

[20] Austin, D. Influence of cation exchange capacity (CEC) in a tidal flow, flood and drain wastewater treatment wetland. Ecol. Eng. 28(1), pp. 35-43, 2006.

[21] Austin, D. and Wallace, S. Energy requirements for nitrification and biological nitrogen removal in engineered wetlands. In: Publicationes Instituti Geographici Universitatis Tartuensis 104 - Proceedings of the $2^{\text {nd }}$ International Symposium on Wetland Pollutant Dynamics and Control, vol. 1, Tartu Estonia, 16-20 September, pp. 45-47, 2007.

[22] Stein, O. R. and Hook, P. B. Temperature, plants and oxygen: how does season affect constructed wetland performance? In: Publicationes Instituti Geographici Universitatis Tartuensis 94, pp. 37-43, 2003.

[23] Jenssen, P. D. and Krogstad, T. Design of constructed wetland using phosphorus sorbing lightweight aggregate (LWA). In: Constructed Wetlands for Wastewater Treatment in Cold Climates. Advances in Ecological Sciences 11, Ü. Mander and P.D. Jenssen (eds.), WIT Press, Southampton, Boston, pp. 259-270, 2003.

[24] Põldvere, E., Karabelnik, K., Noorvee, A., Maddison, M., Nurk, K., Zaytsev, I. and Mander, Ü. Improving wastewater effluent filtration by changing flow regimes - investigations in two cold climate pilot scale systems. Under revision. Ecol. Eng., 2008. In press.

[25] Cooper, P. A review of the design and performance of vertical-flow and hybrid reed bed treatment systems. Wat. Sci. Tech., 40(3), pp. 1-9, 1999

[26] Kadlec, R.H. The inadequacy of first-order treatment wetland models. Ecol. Eng., 15(1), pp. 105-119, 2000.

[27] Vymazal, J., Brix, H., Cooper, P. F., Haberl, R., Perfler, R. and Laber, J. Removal mechanisms and types of constructed wetlands. In: Constructed Wetlands for Wastewater Treatment in Europe, J. Vymazal, H. Brix, P. F. Cooper, M. B. Green and R. Haberl (eds.), Backhuys Publishers, Leiden, The Netherlands, pp. 11-60, 1998. 